\title{
The Sheikh and the Missionary: Notes on a Conversation on Christianity, Islam and Kurdish Nationalism
}

\author{
Owen Robert Miller \\ Bilkent University \\ Kamal Soleimani* \\ El Colegio de México, Centro de Estudios de Asia y África
}

\section{Introduction}

$\mathrm{O}$ $\mathrm{n}$ the morning of October I I, I88I, Henry Otis Dwight, an American missionary and newspaper correspondent for the New York Tribune paid a visit to the Kurdish Naqshbandi Sheikh Ubeydullah. For the last few months, Sheikh Ubeydullah, originally from the Hakkâri region, south of Lake Van, had been living in a house near the Y1ldız Palace in Istanbul. As the preeminent Naqshbandi sheikh in the Ottoman Empire, descended from the Prophet Muhammad and with hundreds of thousands of ardent followers, Sheikh Ubeydullah was accorded a certain amount of official respect, receiving food daily from Sultan Abdülhamid II's personal kitchen. However, he was also, as Dwight observed, "for all intents and purposes a prisoner." I

A year before this meeting, in October I880, Sheikh Ubeydullah had led a predominantly Kurdish army into the northern plains of the Qajar Empire. ${ }^{2}$ Over the course of ten days, part of Ubeydullah's army would lay siege to the city of Urmia. Although his exact intentions have

I ABCFM 600/328, Dwight to Rev. Clark, October I2, I88I, p. I.

${ }^{2}$ See Sabri Ateş's insightful paper, "In the Name of the Caliph and the Nation: The Sheikh Ubeydullah Rebellion of I880-8I," Iranian Studies, 47 (5) (20I4), pp. 735-798. 
been subject to much debate, many scholars have followed Wadie Jwaideh's assertion that Sheikh Ubeydullah's primary aim had been ideological: "to unite the Kurds and to set up an independent Kurdish state."3 Other scholars have just as adamantly argued that while Sheikh Ubeydullah used the language of nationalism, his real concerns lay in the corruption of Ottoman officials, the rise of Armenian nationalism and the devastation and famine conditions of the post-OttomanRussian War of I877-I878. ${ }^{4}$

In any case, Sheikh Ubeydullah's uprising was relatively short-lived. The Qajar military employed extreme violence to crush the uprising, sending waves of Sunni Kurdish refugees into Ottoman territory. ${ }^{5}$ By the end of November, Sheikh Ubeydullah returned to his village on the Ottoman side of the border. In July I88I, Sheikh Ubeydullah was conveyed by the Ottoman authorities to Istanbul. According to the Tabriz-based missionary Samuel Graham Wilson, Sheikh Ubeydullah was escorted by two batteries of artillery and a full regiment of cavalry, "ostensibly as a guard of honor, but really as his custodians." Along the way, he was honored by officials and met with adoring crowds, perhaps encouraged by the rumor that he would soon be appointed to a high position within the Ottoman State. ${ }^{6}$

These rumors continued even after Sheikh Ubeydullah's arrival in Istanbul, where he remained a focus of reverence for his followers. ${ }^{7}$ Dwight would later recall that "men of all ranks would throw themselves at his feet, and sit there for hours with closed eyes, drinking in his spiritual influence."

Perhaps it was partly due to his popularity that the Ottoman State surrounded Sheikh Ubeydullah with spies and requested that he avoid any sort of interaction with foreigners. ${ }^{9}$ It is thus not surprising that to avoid undue attention, the Istanbul-born and raised Dwight donned a fez before meeting Sheikh Ubeydullah in October of I88I. (Henry Otis Dwight was adept at blending in. He had been born to missionary parents in Istanbul in I843. ${ }^{\mathrm{IO}}$ Like many American-

\footnotetext{
3 Wadie Jwaideh, “The Kurdish Nationalist Movement: Its Origin and Development," PhD dissertation, Syracuse University, I960, p. 224. The notion that Sheikh Ubeydullah was after some sort of autonomous Kurdish state can be supported by missionary and consular sources. For instance, according to Rev. Samuel Wilson Graham Wilson, Sheikh Ubeydullah was "ambitious" and "had formed the project of an independent Kurdistan, after the manner of Bulgaria, uniting all the Kurds under his own rule." See, Persian Life and Customs (New York, I895), p. I IO. For a nuanced analysis of Sheikh Ubeydullah's intentions, see Ateş 20I4, pp. 79I-794 \& Soleimani 20I6, pp. I57-2I5. Rev. Robert E. Speer, secretary of the American Presbyterian Mission, wrote that Ubeydullah, "had conceived the ambition of establishing an independent Kurdistan, uniting all the Kurds under his rule, and governing them justly, after his rough Kurdish notions, as a free state." "The Hakim Sabib": The foreign doctor; a biography of Joseph Plumb Cochran (New York, Fleming H. Revell, I9II), p. 74; Speer here concurs with the contemporary assessment of British Consul-General William Abbott, see Turkey No. (5), Abbott to Mr. Thomson, Oroomiah, October 7, I880, p. 72.

4 Abbas Vali, Kurds and the State in Iran: The Making of Kurdish Identity (I.B. Tauris, 20I4), p. I; Martin van Bruinessen, Agha, Shaikh and State: The Social and Political Structures of Kurdistan (Zed Books, I992), p. 250.

5 On this suppression and atrocities, see Ateş 20I4, pp. 762-766; Wilson I895, pp. II5-II7.

${ }^{6}$ Wilson I895, p. II9.

7 [Henry O. Dwight] New York Daily Tribune, September IO, I88I.

${ }^{8}$ Henry O. Dwight I887, p. I88.

9 ABCFM 600/328, p. I, [Henry O. Dwight] New York Daily Tribune, September I0, I88I; and Henry Otis Dwight, "Notes on the Naqshbandi Dervishes" The Andover Review August I887, p. I88.

Io The National Cyclopædia of American Biography, vol. X (New York, James T. White \& Company, I990), p. 490.
} 
Ottomans, he grew up speaking fluent Turkish, Armenian, and English.) After being received in a great hall Dwight was quickly ushered into the Sheikh's bedroom. For two and a half hours the missionary and the sheikh conversed "in the most free and familiar manner" about religion, education, and the Kurdish Sheikh's aspirations.

As we will argue in this paper, the contours of this conversation reveal about much of the complex encounter between Kurdish Sufis and American missionaries in the Hakkâri region. The conversation illuminates the motivations for Sheikh Ubeydullah's I880 uprising and the goals of the American missionaries in the Ottoman Empire, and their encounter underlines the capacity for the religiously convinced to hold sincere respect for the beliefs of religious Others. This article will examine the context of this conversation by investigating how the Ottoman conquest and colonization of its mountainous highlands had at first strengthened and encouraged the growth of both the Naqshbandi Sufis and American Board missionaries during the time of Seyyid Taha and Harrison Gray Otis Dwight (I830s-I860s), the fathers of Ubeydullah and Henry Dwight. Ubeydullah and Henry Otis Dwight would diverge from the patterns of their fathers by stressing, each in their own way, a respect for the beliefs and practices of religious Others. Before venturing further into their conversation, it might be useful to provide short biographies of each of these interlocutors and their respective religious institutions.

\section{$* * *$}

Initially, we will examine how the relationship between the Ottoman conquest of the Kurdish principalities in the I9 ${ }^{\text {th }}$ century led to the rise of Naqshbandi Sheikhs. In the second section, we will recount how Sheikh Ubeydullah's relationship with the missionaries grew out of his attempts to set up an independent polity at the edges of the Ottoman and Qajar Empires. In a time of increasing sectarian violence, Sheikh Ubeydullah made great efforts to protect the Christian population of the Urmia region and the American missionaries. Finally, we will show how the same processes of Ottoman centralization (or, conquest and colonization) that enabled the Naqshbandi Order to acquire political power in the mountainous highlands of the east also enabled the American Board of Commissioners for Foreign Missions (ABCFM), the largest group of American missionaries, to establish missionary stations in the same regions. Much as the Naqshbandi and the ABCFM have hitherto been studied in completely separate historiographies, both organizations were 'revivalist' and flourished in a period of socio-economic and political crisis. Much as the Naqshbandi and the ABCFM bore some unexpected commonalities, the lives of Dwight and Ubeydullah, also exhibited some parallels and convergences. Unlike their fathers, however, who both were both zealous missionaries, intolerant of their Others, Sheikh Ubeydullah and Dwight approached the religion of the Other with a striking sensitivity.

\section{Part I: Ubeydullah and the Naqshbandi in Nehri}

Sheikh Ubeydullah was born in the late I820s or early I830s, in the small village of Nehri, between Lake Van and the foothills of the Hakkâri mountains. Years later, the name of his village would serve as his pen name. As later described by F.A. Maunsell, a British military attaché, later described it, Nehri was "a large village prettily situated in a side valley off the main 
gorge ensconced amid walnut groves and orchards." "I At the time, the Ottoman Empire was composed of what one observer called an "aggregate of kingdoms, principalities, and republics." 22 The predominantly Armenian- and Kurdish-speaking territories of the Ottoman Empire were ruled by a number of semi-autonomous polities, the largest of which included Soran, Bitlis, Hakkâri, Bahdinan and Bohtan. ${ }^{\mathrm{I} 3}$

Making use of a conscript-military, drilled by former Napoleonic officers and armed with the latest firearms, Sultan Mahmud II (r. I808-I839) endeavored to bring these territories under his direct rule. ${ }^{\mathrm{I}}$ Centralization, of course, is a word favored by those who place the historical camera in the seat of Empire. From the perspective of many beyond the reach of Istanbul, this process, which unfolded over the course of decades, resembled nothing less than conquest or colonization. ${ }^{\mathrm{I}}$ In I834, Reşid Mehmed Paşa, formally appointed the governor-general of

${ }^{\text {II }}$ F.A. Maunsell, "Central Kurdistan,” Geographical Journal I8 (I90I), p. I40.

${ }^{I 2}$ It is not clear when Ubeydullah was born. According to Dwight, Ubeydullah was about 45 years old in I88I, while Rev. Cochran estimated that he was 53 in I880. Using these as a range, Ubeydullah would have likely been born between I827 and I836. See ABCFM 600/328, p. I; Speer I9II, p. 79; Alışan Akpınar states that Ubeydullah was born in Nehri, see "Modernleșen Kürdistan'ın İlk Lideri Şeyh Ubeydullah: (Es Seyyid Ubeydullah el-Nakşibendi el-Halidi) in Yalçın Çakmak and Tuncay Şur (eds), Kürt Taribi ve Siyasetinden Portreler (Iletişim, 20I8); for the observation that the Ottoman Empire consisted of an "aggregate of kingdoms," see Helmuth von Moltke, Briefe ïber Zustände und Begebenheiten in der Türkei aus den Jahren 1835 bis 1839 (Berlin, I876, originally published in I84I), p. 45 .

13 On the Emirates, see, Maurizio Garzoni, Grammatica e Vocabolario Della Lingua Kurda (Rome, 1787), pp. 3-4; Michael Eppel, "The Roots of Modern Kurdish Nationalism," in Kurdish Awakening: Nation Building in a Fragmented Homeland (University of Texas Press, 20I4); F.A. Maunsell, "Kurdistan," Geographical Journal 3 (I894), p. 82; Metin Atmaca, "Resistance to centralization in the Ottoman periphery: The Kurdish Baban and Bohtan emirates," in Middle Eastern Studies (February, 2019). For a brief overview, see Metin Atmaca, "Three Stages of Political Transformation in the $\mathrm{I}^{\text {th }}$ century Ottoman Kurdistan," in Anatoli: De l'Adriatique à la Caspienne: territories, politique, sociétés 8 (20I7).

${ }^{14}$ For the conscript military, see Y. Hakan Erdem, "Recruitment for the "Victorious Soldiers of Muhammad" in the Arab provinces, I826-I828" Israel Gershoni, Y. Hakan Erdem and Ursula Woköck (eds) Histories of the Modern Middle East: New Directions (Boulder: Lynne Rienner Publishers, 2002); idem, “Turks as soldiers in Mahmud II's army: turning the Evlad-1 Fatihan into regulars in the Ottoman Balkans," Sabine Rutar (ed), Beyond the Balkans: Towards an Inclusive History of Southeastern Europe (Zurich \& Berlin: Lit Verlag, 2OI4) pp. 227-246.

20I4, Virginia Aksan, "Mobilization of warrior populations in the Ottoman context, I750-I850," in Erik Jan Zürcher (ed) Fighting for a Living: A Comparative Study of Military Labour, I500-2000 (Amsterdam University Press, 20I3); Veysel Şimşek, "The First 'Little Mehmeds': Conscripts for the Ottoman Army," Osmanl Arasttrmalarn 44 (20I4), pp. 265-3II.

${ }^{15}$ For the debate about the Ottoman Empire and colonization, see Özgür Türesay, "The Ottoman Empire Seen through the Lens of Postcolonial Studies: A Recent Historiographical Turn," Revue d'bistoire moderne et contemporaine 60, no. 2 (20I3), pp. I27-I45; Ussama Makdisi, "Ottoman Orientalism," American Historical Review 2002; Selim Deringil, “They Live in a State of Nomadism and Savagery': The Late Ottoman Empire and the Post-Colonial Debate," Comparative Studies in Society and History vol. 45, no. 2 (2003), pp. 3II-342; Thomas Kuehn, Empire, Islam, and Politics of Difference (Brill, 20II), and Mostafa Minawi, The Ottoman Scramble for Africa (Stanford University Press, 20I6) More broadly, see Michael Hechter, Internal Colonialism: The Celtic Fringe in British National Development, 1536-1966 (UC Press, 1975) and Michael Adas, "Imperialism and Colonialism in Comparative Perspective," International History Review vol. 20, no. 2 (I998), pp. 37I-388. 
Diyarbekir, began a violent campaign to eradicate the power of the semi-autonomous emirates. ${ }^{\mathrm{I}}{ }^{6}$ Upon his death in I836, this campaign was continued by Hafız Mehmed Paşa. ${ }^{17}$ Local rulers were replaced with bureaucrats and military officers sent from Istanbul, and the hilltop castles of local rulers (derebey, ayan or mir) were replaced with barracks, prisons, and schools.

This was often a violent process. ${ }^{18}$ In the spring of I882, shortly after the Sheikh arrived in Istanbul, the British consular officer Herbert Chermside traveled in the mountainous regions that had been newly brought under direct rule. He wrote that the

desolation that has been wrought by the [Ottoman] Government in this district only so recently subdued is complete and shocking. There are far more deserted villages than inhabited ones, the latter reduced in size, with inhabitants for the most part abjectly poor and squalid. The mosques and medressehs [sic] of former Mirs, Sheikhs, and Begs are all in ruins. The Rayahs, both Kurdish and Christian, have suffered terribly ... ${ }^{19}$

According to Garo Sasuni, the Ottoman efforts to break the power of the "secular" rulers in the mountainous east contributed directly to the rise of the sheikhs. ${ }^{20}$ After the fall of the Bohtan Emirate, Sheikh Ubeydullah's father, Seyyid Taha, began to assert political power. ${ }^{2 \mathrm{I}}$ In many respects, this politicization of religious authority was happening elsewhere at roughly the same time and for similar reasons. Briefly, as colonizing authorities replaced "secular" rulers with their own military might, they almost always left religious structures intact. Colonizing authorities often attempted to use these religious authorities as agents to exert their control. Yet, some of these religious organizations became vehicles of resistance to colonial rule. The Ottoman colonial rule was not an exception.

Geography played a role. Until the middle of the nineteenth-century, mountainous regions lay outside the direct control of lowland states. Using the technologies of the industrial age (steam, telegraph, and rifles), lowland states around the world began to move into upland

\footnotetext{
${ }^{16}$ Suavi Aydın and Jelle Verheij, "Confusion in the Cauldron: Some Notes on Ethno-Religious Groups, Local Powers, and the Ottoman State in Diyarbekir Province, I800-1870," in Joost Jongerden and Jelle Verheij (eds), Social Relations in Ottoman Diyarbekir, 1870-1915 (Brill, 2012), pp. 30-32. Barbara Henning, Narratives of the History of the Ottoman-Kurdish Bedirbani Family in Imperial and Post-Imperial Context: Continuities and Changes (University of Bamberg Press, 20I8), pp. 96-97.

${ }^{17}$ Jongerden and Verheij 20I2, pp. 32-34.

${ }^{18}$ For brief discussions of the violence, see von Moltke I876 p. 273, Justin Sheil, "Notes on a Journey from Tabríz, Through Kurdistan, via Vân, Bitlis, Se'ert and Erbil, to Sulaymaniyah, in July and August, I836," in Journal of the Royal Geographic Society of London, vol 8 (I838), p. 85; Frederick Millingen, La Turquie sous le regne d'Abdul-Aziz (1862-1867) (Paris, I868), p. I9; William Ainsworth, Travels and Researches in Asia Minor, Mesopotamia, Chaldea, and Armenia (London, I842), vol. I: p. 25I and 293 and 297; Horatio Southgate, Narrative of a Tour Through Armenia, Kurdistan, Persia and Mesopotamia, vol. I: pp. $263-264$ and 267; Sasuni 1992, pp. 97-98, citing von Moltke.

${ }^{19} \mathrm{FO}$ 424/I32, Lieutenant Chermside, R.E. to Colonel Sir C. Wilson (Diarbekir, April 30, I882), p. I39.

${ }^{20}$ Garo Sasuni, Kürt ulusal hareketleri ve 15. Yüzylldan günümüze Ermeni Kürt İliskileri (Med Yaynevi, I992), pp. I35-I68; see also Wadie Jwaideh I960, pp. 2I2-290; Martin van Bruinessen I992, pp. 205-264.

${ }^{21}$ Martin van Bruinessen I992, p. 23I; Joyce Blau, "Le Rôle des Cheikhs Naqshbandī dans le Mouvement national Kurde," in Marc Gaborieau, Alexandre Popovic and Thierry Zarcone (eds), Naqsbbandis: Cheminements et situation actuelle d'un ordre mystique musulman (Istanbul, I990), p. 373.
} 
spaces. ${ }^{22}$ Analogies might be drawn between the French scorched-earth campaigns into the Atlas Mountains, the Russian conquest of the Caucasus, and the British efforts to control the 'tribal' areas on the frontiers of its South Asian Empire. ${ }^{23}$ Over the course of the $19^{\text {th }}$-century the Ottoman State employed the same toolkit to conquer the mountainous fringe as Western empires did on their peripheries. ${ }^{24}$

These mountainous regions were exceedingly diverse linguistically, religiously and politically. As colonizing authorities - Russian, French, British or Ottoman - slowly made their way into their upland frontiers, locals often employed religion as a means to unite hitherto divided mountain communities against outsiders. The history of Sheikh Ubeydullah in the Hakkâri mountains might be usefully compared to histories of Imam Shamil in the Caucasus, Abdelkader in the Atlas, and Mirza Ali Khan (Faqir of Ipi) in Waziristan. ${ }^{25}$ All of these figures used the mantle of religious authority to organize political resistance against outsiders. It is not a coincidence that each of these men was the head of a Sufi order, Naqshibandi in the cases of Imam Shamil and Sheikh Ubeydullah, and Qadiriyya in the case of Abdelkader and Mirza Ali Khan.

Sheikh Ubeydullah was the son of Seyyid Taha, a prominent spiritual and political figure in his own right. Seyyid Taha was brought up within the order of Qadiriyya Sufism. His family clamed not only to be related to the Prophet Muhammad, but also to Abdul Qadir Gilani (c. I077 - II66 CE), the founder of the Qadiriyya Order (tariqa). Shortly before Sheikh Ubeydullah was born, Seyyid Taha, along with most of his family, converted from the Qadiriyya Order to a new form of Naqshbandi Sufism that spread just as the Ottomans began to conquer the Kurdish Emirates.

The roots of Naqshbandi Sufism lay in communities of holy teachers, or spiritual masters (Farsi: Khwājagān) in I2th century Bukhara in what is present-day Uzbekistan. In the I4th century, a certain Baha'uddīn Naqshband reorganized the Order which thereafter bore his name. Over the following centuries, Naqshbandi Sufism made inroads in South Asia, Central Asia, the Caucasus, and the Middle East. In the I $6^{\text {th }}$ century, the Punjabi jurist Ahmad al-Fārūqī al-Sirhindī radically revitalized the Naqshbandi Sufism again, stressing the interplay between law (Shari'a)

\footnotetext{
22 James C. Scott, Art of Not Being Governed: An Anarchist History of Upland Southeast Asia (Yale University Press, 2OIO).

23 Dierk Walter, Colonial Violence: European Empires and the Use of Force (Oxford University Press, 2OI7).

${ }^{24}$ Chris Gratien, "The Mountains are Ours: Ecology and Settlement in Late Ottoman and Early Republican Cilicia, I856-I956," PhD dissertation, Georgetown University, 2015.

${ }^{25}$ Moshe Gammer, "Empire and Mountains: The Case of Russia and the Caucasus," Social Evolution \& History vol. I2, No. 2 (September 2013); Knut S. Vikør, "Religious Revolutions in Colonial North Africa," in David Motadel (ed), Islam and European Empires (Oxford University Press, 20I4); Alan Warren, Waziristan, the Faqir of Ipi and the Indian Army: The North West Frontier Revolt of 1936-37 (Oxford University Press, 2000). One could extend this list to include tariqat organized in arid climes as well, such as Pir Pagaro of Sindh, Seyyid Mohammed Abdullah Hassan of Somalia (Qadiriyya), and Muhammad Ahmad bin Abd Alla (Samaniyya) in the Sudan.
} 
and mysticism. ${ }^{26}$ Under the pretext of purifying religion and returning to a 'lost pristine Islam,' revivalist movements often reflected popular discontent. At certain points, this was used to support the status-quo, at other times to challenge it. Ahmad al- Sirhindī's version of Naqshbandi Sufism would prove exceedingly influential, first in the Mughal Empire, and later around the world.

In the early I9 ${ }^{\text {th }}$ century, Mawlana Khālid-i Bagdadi (or Kurdi), born in a village near the city of Sulaymaniyah in present-day Iraqi Kurdistan, traveled to India and converted to Naqshbandi Sufism. ${ }^{27}$ Mawlana Khālid-i returned to Sulaymaniyah where he soon created a new form of Naqshbandi Sufism that stressed resistance to powerful outsiders, or anti-Imperialism, that quickly spread from the Balkans to Southeast Asia.

According to Itzchak Weissmann, the practitioners of Khālīilyya Naqshbandi Sufism embraced the notion from al-Sirhindi that, "mystic experience is subordinated to the precepts of the Shari'a and that if it negates them it becomes nothing but unbelief." 28 Such views are echoed in the writings of Sheikh Ubeydullah, whose father was one of the khalifas (followers) of Mawlana Khālid. ${ }^{29}$ Ubeydullah contended that "Islamic laws were nothing more than the Qur'anic verses and the Prophetic tradition and therefore anything incompatible with these two was but forbidden innovation (bid'a)." 30 It is important to stress here that Sheikh Ubeydullah's focus on renewal

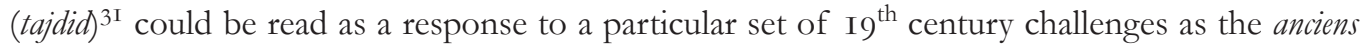
régimes of the Kurdish mirs were swept away by the Russian, Ottoman and Qajar conquest of mountain spaces.

According to Sheikh Ubeydullah, the mid-I $9^{\text {th }}$ century was not a period of progress but one of destruction and tumult. One indication of this unraveling was the destruction of local centers of knowledge. Ubeydullah represented the half-century before the imposition of direct Ottoman rule as a period where people "from every region and every ethnic origin [qawm, Arabic, and qowm, Persian]" came to Kurdistan to harvest its fruits of knowledge. ${ }^{32}$ Compared to the period before the conquest, "those seas of knowledge and illumination" dissipated and what was left

\footnotetext{
${ }^{26}$ Hamid Algar, "A Brief History of the Naqshbandī Order," in Marc Gaborieau, Alexandre Popovic and Thierry Zarcone (eds), Naqshbandis: Cheminements et situation actuelle d'un ordre mystique musulman (Istanbul, I990), pp. 20-23; Itzchak Weismann, The Naqshbandiyya: Orthodoxy and activism in a worldwide Sufi tradition (Routledge, 2007), pp. 49-67.

${ }^{27}$ Claudius James Rich, Narrative of a Residence in Koordistan and of the Site of Ancient Nineveh (London, I836) vol. I: pp. I40-I4I; Algar I990, pp. 28-32; Albert Hourani, The Emergence of the Modern Middle East (UC Press, I98I), pp. $8 \mathrm{I}-86$.

${ }_{28}$ Itzchak Weissmann, Taste of Modernity: Sufism, Salafiyya, and Arabism in Late Ottoman Damascus (Brill, 200I), p. 30.

29 Mehmet Çakır, "XIX. Yüzyılda Tarikat-Siyaset İlişkisi: Nehri Tekkesi Örneği," Turkish Studies: International Periodical for the Languages, Literature and History of Turkish or Turkic II (20I6), pp. 58-67.

30 Soleimani 20I6, p. I66 Mesnewi Șex Ubeydullah Nehri, TuhfetulEhbab (ed. Seyid Islam Duagû) (Urmia: Husseini, 200I), p. III; see also Mehmet Saki Çakır, "Şeyh Ubeydullah Nehrî’nin Mesnevîsi: Tuhfetü’l-Ahbâb,” e-Şarkiyat İmi Arasttrmalar Dergisi 8:I (April 20I6), pp. 545-549.

${ }^{31}$ Muhammad Iqbal claims that the idea that a mujaddid (renovator) appears at the head of every century was

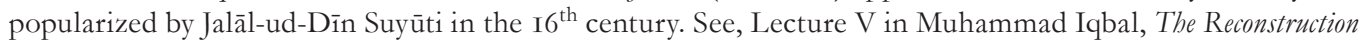
of Religious Thought in Islam (Stanford University Press, 20I3), reprint.

${ }^{32}$ Nehri, Tuhfetul Ehbab 2000, p. I28.
} 
was nothing but a façade. ${ }^{33}$ Herbert Chermside echoed this dire assessment, noting that "Churches, convents, mosques, medressehs, bridges, and aqueducts, all now in ruins testify to the former existence in comparatively recent times of a far larger and more civilized population."34

The ruins (churches, convents, mosques, and madrasas) that Chermside observed were a consequence of Ottoman colonial expansion. Alongside the introduction of steam-power shipping in the Black Sea, and the near-contemporary advent of low tariffs on mass-produced European products, the Ottoman conquest of the semi-independent polities, and the removal of their rulers created a power vacuum. ${ }^{35}$ Into this power vacuum grew a complicated set of relationships between newly empowered bandit-warlords and Ottoman bureaucrats. These relationships are well documented in hundreds of reports by consuls, missionaries, and travelers. Local notables who backed the Ottomans were often rewarded with bureaucratic positions. In other cases, centrally appointed bureaucrats formed symbiotic relationships with the local notables based on a policy of extraction from the local population. ${ }^{36}$ Opportunities for corruption were rife. All of these changes in governance were concomitant with increased violence, famine, and struggles over diminishing resources. ${ }^{37}$

For Yezidi communities of the eastern Taurus, the replacement of the older mir-system with Ottoman centralized rule was disastrous. According to von Moltke, Ottoman soldiers were encouraged and allowed to destroy not just the combatants who resisted them, but entire villages because the inhabitants were Yezidi. ${ }^{38}$ Just like the term Alevi today, the term Yezidi encompassed many different localized religious practices and traditions. As with most mountain people beyond the reach of the State, their practices were highly localized. ${ }^{39}$ During the $19^{\text {th }}$ century,

\footnotetext{
33 Ibid.

${ }^{34}$ FO 424/I32, Lieutenant Chermside, R.E. to Colonel Sir C. Wilson (Diarbekir, April 30, I882), p. I39, italics added. For a rare analysis of the extent of manuscript production in the Emirate of Hakkâri, see Alexander Khachatrian, "The Kurdish Principality of Hakkariya (I4th-I5th Centuries)," Iran \& the Caucasus, vol. 7 (2003), pp. 37-58.

35 Jwaideh I960, p. 2I3.

${ }^{36}$ In I882 Chermside reported that the "weaving industry of shawls, cloths, \&c., has much declined in the mountains." (op. cit) Other examples of this pattern can be found in Owen Robert Miller, "Sasun I894: Mountains, Missionaries and Massacres at the End of the Ottoman Empire," PhD dissertation, Columbia University, 2015 .

37 The relationship between famines and the expansion of Ottoman direct rule begs further research. By the I850s, soon after the overturning of the Beys, famine was reported in the mountainous eastern regions of the Empire that was, according to some accounts "greater than had been known in the last century." (see Missionary Herald, I859, p. 303). For the complex relationship between capitalism, colonialism and famine, see Mike Davis, Late Victorian Holocausts: El Niño Famines and the Making of the Third World (Verso, 20I7), reprint.

38 Moltke I876, p. 274.

39 Henry H. Riggs, "The Religion of the Dersim Kurds," in The Missionary Review of the World vol. 34 (I9II), p. 735; George Frederick Abbott, Turkey in Transition (London, I909), p. 68; Hormuzd Rassam, Asshur and the land of Nimrod (New York, I897), p. I04; David George Hogarth, A Wandering Scholar in the Levant (London, I896), pp. II9-I2O.
} 
many travelers reported that areas between Bohtan and Hakkâri were inhabited by large numbers of Yezidi. ${ }^{40}$

Nonetheless, Sheikh Ubeydullah's father, Seyyid Taha (along with other Naqshbandi Sheikhs), likely benefited from the destruction of localized religious traditions like Yezidism. ${ }^{4 \mathrm{I}}$ According to a number of sources, Sheikh Taha played a key role as an adviser to Emir Bedirhan to carry out mass violence against the Assyrian communities of Tiyari in I $843 .{ }^{42}$ The Biblical scholar and archeologist Edward Robinson wrote that it is likely that both Emir Bedirhan of Bohtan and Nurullah Beg of Hakkâri were acting under the orders of the Ottoman authorities who often used divide et impera tactics to conquer and control territory. ${ }^{43}$ As Major Trotter put it succinctly, "the policy of the [Ottoman] government has always hitherto been to set tribe against tribe."44

Nehri and its surrounding area of Shemdinan or Nochea (derived from Kurmanji Kurdish navchiya: between the mountains) had long been an area with a complex tapestry of religious identities. According to an early $2 \mathrm{O}^{\text {th }}$ century account by Anglican missionaries the advent of Ottoman rule had dramatically altered these relations:

The villages of Nochea, Kurdish and Christian, are beautifully scattered in the valleys and on the hillsides and possess some of the oldest and best of the Syrian churches, built entirely of stone, and often containing seven or eight divisions. The old name of the district was Rustaka ("black mountains") which picturesquely describes its beautiful mountains covered with dark forests. In olden days it was under the expensive protection of the Kurdish chiefs, and until quite lately some of the villages were Ashiret. In recent times the Turks have asserted their authority, and by destroying the Kurdish protection have changed their powerful neighbours into oppressive robbers. ${ }^{45}$

Rev. Wright and Dunkha, an Assyrian priest, who visited Seyyid Taha in I847 were left with a decidedly mixed impression: they describe Seyyid Taha as both a 'Koordish Saint' and a 'fanatic.' On the one hand, once Seyyid Taha learned that the missionaries had "no connection with the [Ottoman] Government" he received them with kindness and gave them a "paper,

${ }^{40}$ See, Xavier Hommaire de Hell, Voyage en Turquie et en Perse (I854), p. 475 and more recently, Suavi Aydın and Jelle Verheij, "Confusion in the Cauldron: Some Notes on the Ethno-religious groups, local powers and Ottoman State in Diyarbekir Province, I800-I870," in Joost Jongerden and Jelle Verheij (eds), Social Relations in Ottoman Diyarbekir, 1870-1915 (Brill, 20I2), p. 3I. For violence against the Yezidi more broadly see also Edip Gölbas1, “Turning the 'Heretics' into Loyal Muslim Subjects: Imperial Anxieties, the Politics of Religious Conversion, and the Yezidis in the Hamidian era," The Muslim World IO3, issue I (20I3), pp. 3-23.

${ }^{41}$ Aydin and Verheij 20I2, op. cit, p. 38, fn. IO4.

42 Austen Henry Layard, Nineveh and Its Remains (London, I849), voI. I: pp. I93-I94; Hans-Lukas Kieser, Der verpasste Friede: Mission, Ethnie und Staat in den Ostprovinzen der Türkei, 1839-1938 (Chronos, 2000), pp. 64-68; The Missionary Herald, vol. 39 (I843), p. 435; Jwaideh I960, pp. 204-205.

${ }^{43}$ See Edward Robinson's introductory note in Austen Henry Layard, Nineveh and its remains (New York, I850), vol. I: p. viii. For an interesting examination of how the Ottoman State divided and ruled, see Frederick Millingen, Wild Life Among the Koords (London, I870), pp. 57-58.

44 Turkey No. 5 (I88I), Major Tribe to Mr. Goschen, Therapia, October 20, I880, p. I6.

${ }^{45}$ Francis Nicholson Heazell and Jessie Payne Smith Margoliouth, Kurds \& Christians (London, I9I3), p. 63-64. 
certifying that we were his friends, and that any persons who should trouble us, or any of our native helpers in any way, would meet with his displeasure." On the other hand, he reportedly carried out death sentences against apostates and "in I843, when Noorullah Bey and Bader Khan Bey were planning the invasion of Tiyary issued a proclamation, that all who joined the invading army were doing God service, and thus gave a religious character to the war, which added greatly to the horrors of it." 46

As very little is known about Ubeydullah's upbringing, or relationship with his father, it is difficult to even speculate on what qualities he inherited from his father. By the mid-I860s, Ubeydullah had succeeded his father as the head of the Naqshbandi lodge (tekke) in Nehri. In the vicinity of this tekke, Sheikh Ubeydullah controlled what amounted to a miniature state. Travelers reported that taxes were paid to Sheikh Ubeydullah, not to Istanbul. ${ }^{47}$ According to Russian consular reports, by the early I870s, the Qajar State was beginning to demand direct taxes from villages in lieu of tributary relations with Ubeydullah. ${ }^{48}$

During the calamitous Ottoman-Russian War of I877-I878 Sheikh Ubeydullah led a contingent of irregular soldiers. ${ }^{49}$ While some accounts claim that Sheikh Ubeydullah was involved in wartime atrocities, others claim he protected the local Christian population..$^{50}$ In any case, it was likely during the war, or immediately after, that he decided to create an independent Kurdistan. ${ }^{5 \mathrm{I}}$ Most of the copious missionary accounts of Ubeydullah were written after this point. Many of the American Presbyterian missionaries living in Qajar Iran held Sheikh Ubeydullah in high regard. They stress that while Sheikh Ubeydullah may have inherited the mantle of 'sainthood' from his father, he was quite different in temperament. According to the missionaries he was an

${ }^{46}$ Missionary Herald, Vol. 44, "Letter from Doct. Wright, Sept. IO, I847," pp. 56-57.

${ }^{47} \mathrm{FO}$ 424/I07, Captain Clayton to Major Trotter, August 2, I880, p. I97.

${ }^{48}$ Kendal Nezan, "Kurdistan in Turkey," in People without a Country: The Kurds and Kurdistan, edited by Gerald Chaliand (Zed Books: London, 1992), p. 23. For detailed accounts of the transfer of power from Seyyid Taha to Ubeydullah's uncle Salih and finally, in I873 to Sheikh Ubeydullah, and the political economy of Shemdinan, see Mehmet Saki Çakır, "XIX. Yüzy1lda..." op. cit., and Ateş 20I4, pp. 740-744.

49 See Mehmet Firat K1lıç, "Sheikh Ubeydullah's movement," MA thesis, Bilkent, 2003, pp. 8-I8; Ateş 20I4, p. 744; Pyotr Ivanovich Averyanov, Kurdy v voinakh Rossii s Persiey i Turtsiey v techenie XIX stoletiya (Tiflis, I900), translated into Turkish as Avyarov, Osmanl-Rus ve Iran Savașlar'nda Kürtler, 1801-1900 (Sipan, I995), p. 95.

50 There is considerable disagreement about what Sheikh Ubeydullah did, or did not do, during the war. According to the British Consul-General of Tabriz, William G. Abbott, Sheikh Ubeydullah was responsible for atrocities, specifically in Bayazid. (FO 424/IO7, Consul-General Abbott to Earl Granville, Tabreez July 3I, I880, p. I27). However, the Urmia-based Presbyterian missionary, Benjamin Labaree, Jr., cautions that the Ottoman Government "did not hold him responsible for the massacre" but instead "another Sheikh of a more fanatical spirit." Quoted in Plymouth Restitution (Indiana), January I2, I88I. Charles Boswell Norman, a special correspondent with the Times, claimed that men under the command of Sheikh Ubeydullah had attacked and burned villages in the Van district. See, Armenia, and the Campaign of 1877 (London, I878?), p. 298. David McDowall, exonerates Sheikh Ubeydullah's actions during the war, writing that, "In I 878 Ubayd Allah's influence saved many Christians from massacre in Bayazid." See, A Modern History of the Kurds (I.B. Tauris, 2004), fn. 2I, p. 65.

${ }^{51}$ [Benjamin Labaree, Jr.], Plymouth Restitution (Indiana), Jan. I2, I88I; see also Metin Atmaca, "Report by the British Consul on the Sheikh Ubeydullah Revolt in I880-I88I," in Sebastien Maisel (ed), The Kurds: An Encyclopedia of Life, Culture and Society (ABC-CLIO, 2018), pp. 322-323. 
intelligent, curious, and just ruler who, unlike his father consistently protected the Christian population.

According to Rev. Benjamin Labaree, Jr., "Sheikh Obeidullah has come to rank, at least in the minds of Koords, as second in dignity and sanctity only to the great Sheriff of Mecca, whose rank is next to that of the Sultan of Turkey. He holds himself higher than either, and in real ability and fitness to govern, he does not err in his estimate." ${ }^{2}$ This high opinion of Sheikh Ubeydullah's abilities and savvy was echoed in the writings of the Urmia medical missionary Rev. Joseph Plumb Cochran. In the spring of I880, a few months before Ubeydullah's uprising, the Rev. Joseph Plumb Cochran visited Sheikh Ubeydullah in his home village of Nehri. For several years, Ubeydullah had been friendly with the ABCFM missionaries and had extended invitations for them to visit him. ${ }^{53}$ Although Sheikh Ubeydullah was suffering from a bout of illness Cochran was impressed with his ambition, piousness, and prepossession. ${ }^{54}$

According to Cochran, Sheikh Ubeydullah, bedecked in flowing robes and a white turban, was "a man well read in Persian and Arabic literature." 55 Cochran noted that he spoke constantly of God, and strove to "do His will, according to his religion." ${ }^{6} \mathrm{He}$ was, according to Cochran, "[a] just judge," and a "kind lord to his citizens" but could also be "very cruel" when his will was disobeyed. ${ }^{57}$ During his week in Nehri, Cochran observed that the Sheikh's residence was a bustle of activity, with Kurdish chiefs from different parts of the country coming to pay their respects and some 500 to I,OOO people "entertained at this great man's personal expense." 58

Dwight later described this complex in greater detail in the New York Tribune,

Obeidullah's castle was a center of good things to all the Kourds of the border. Besides the private apartments of the Sheikh, and the mosque where he was wont to impart religious instruction, and besides a regularly organized orphan asylum where no applicant was ever denied admittance to the Sheikh's bounty, the castle contained a long series of rooms facing upon the great quadrangle, where Kourds of any tribe or rank might dwell for any reasonable length of time, fed from the Sheikhs kitchen, and without question as to why they came, why they stayed or why they left. .9

After spending a week with Sheikh Ubeydullah, Cochran noted, "On leaving, the Sheikh presented me with his war-horse as a token, he said, of his gratitude to me for visiting him in his illness, and of his firm friendship towards us [missionaries]." 60 One question that is very difficult to ascertain is to what extent this gesture was at least in part pragmatic.

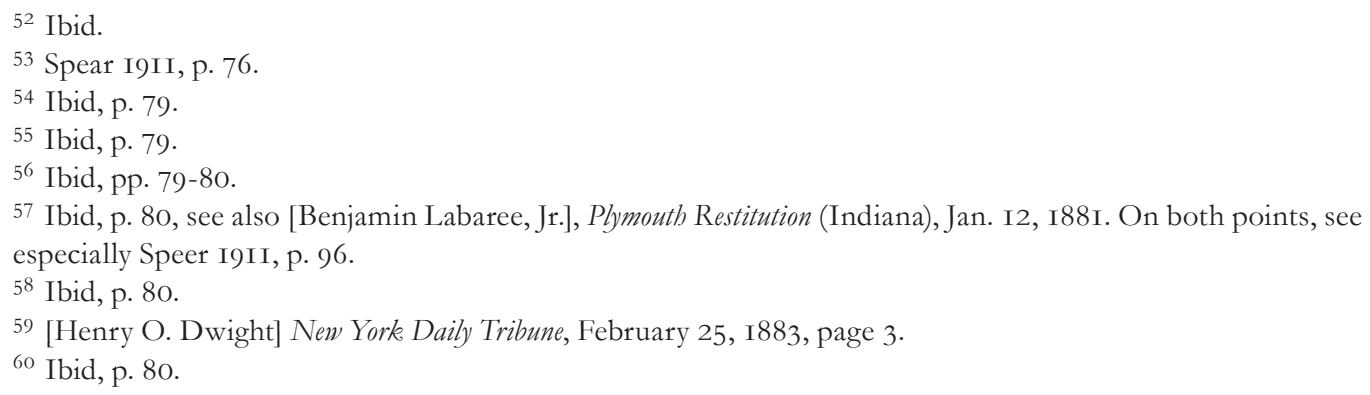


Dr. Cochran had visited Nehri at a critical moment. In I879, in the aftermath of the catastrophe of the I877-I878 Ottoman-Russian War and arguably the worst famine in centuries, Sheikh Ubeydullah's son Abdulkadir had raised a banner of rebellion against the Ottoman State. ${ }^{\text {GI }}$ Abdulkadir's uprising was relatively small and unsuccessful. ${ }^{62}$ Although Sheikh Ubeydullah claimed that he took no responsibilities for his son's actions, it is almost certain that Sheikh Ubeydullah was testing the waters before making a concerted effort to carve out a frontier principality at the edges of the Ottoman and Qajar Empires.

Shortly after Cochran's visit, the British military consul Emilius Clayton reported that Sheikh Ubeydullah had convened a meeting of Kurdish 'chiefs' "ostensibly to console him on his illness." Clayton suspected that there was some "ulterior object also." 63 A week later, on May 25, I880, Clayton reported that "Sheikh Obeyd Ullah is working hard to extend his influence. He is ingratiating himself with the Christians, and large numbers of the latter have migrated from Gevver into the Sheikh's immediate neighborhood in order to enjoy his protection from other Kurds." $" 64$

To secure local support Sheikh Ubeydullah reached out to representatives of the Armenian Church and Mar Shimun XVIII Rubil, the Patriarch of the Assyrian Church in Qodchanis, Hakkâri. ${ }^{65}$ According to Jwaideh, Sheikh Ubeydullah's efforts to cooperate with the local Christian population had at least three goals. First, by creating a "united home front," he would "have greater material and manpower at his disposal for the anticipated struggle" with the Ottoman Empire. ${ }^{66}$ Moreover, Sheikh Ubeydullah may have hoped to undermine alternative 'autonomy' efforts, such as those promoted by Mkrtich Khrimian on behalf of Armenians, a

\footnotetext{
${ }^{61}$ See Özge Ertem, "Considering Famine in the Late Nineteenth Century Ottoman Empire: A Comparative Framework and Overview," Collegium 22 (2017), pp. I5I-I72. According to Ertem, the famine in I880 had led to at least I0,000 deaths in the eastern provinces. Kendal Nezan without citation wrote that this was, "probably the worst famine the Kurdish people had known for centuries." See also Ateş 20I4, fn. 39, p. 744. For more on the famine see copious reports in FO 424/IO6, for instance, pp. 262-264, p. 269, p. 340, p. 348-349, 357, 377, especially pp. 388-397. The forthcoming dissertation by Matthew Ghazarian will no doubt prove critical in our understanding of the interplay between politics and famine in the late Ottoman Empire.

${ }^{62}$ FO 424/I06, Captain Clayton to Major Trotter, Van, February 2, I880, p, 245; Ateş 20I4, p. 745; Jwaideh I960, p. 247.

${ }^{63}$ FO 424/I06, Captain Clayton to Major Trotter, Van, May I8, I880, p. 5 I9.

${ }^{64} \mathrm{FO} 424 /$ I06, Captain Clayton to Major Trotter, Van, Van, May 25, I880, p. 527. The original can be found in FO I95/I3I5 No. 20. Cited in Soleimani 2016.

${ }_{5}^{6}$ FO 424/IO6, Captain Clayton to Major Trotter, Van, February 2, I880, p. 247; FO 424/IO7, Captain Clayton to Major Trotter, Bashkala, July II, I880, p. I05; FO 424/I22 Captain Clayton to Major Trotter, Van, November 27, I880, p. Io; Turkey No. 5 (I88I), Captain Clayton to Major Trotter, Van, November 2, I880, p. 54.

${ }^{66}$ Jwaideh I960, p. 235.
} 
contemporary religious-political leader from the Van region. ${ }^{67}$ Finally, Sheikh Ubeydullah may have hoped that by protecting the local Christian population he would engender European support. $^{68}$

In late July I 880, the British military consul Emilius Clayton paid a visit to Sheikh Ubeydullah's home at Nehri. Clayton reported that he was received with distinction, "the Sheikh having sent all the principal people out to meet me, and lodging me in his own house, a favour which I am told he did not accord to Bahri Bey when he was there recently as the bearer to the Sheikh of the decoration sent by the Sultan." During their first public meeting, Sheikh Ubeydullah said that, "it was his constant desire and effort to improve the condition of and give security to the people of all nationalities and creeds." Clayton observed that Sheikh Ubeydullah "was most anxious I should believe he cared for all nationalities and religions alike" and, "that the blame for the present state of things lay at the door of the Government and of some of its officials and others who were interested in the maintenance of the present disorder." ${ }^{69}$ During their private meeting, the Sheikh was even more explicit:

The Sheikh said that to speak openly, though he was a Turkish subject, his sympathies were with England, because he was in communication with Sheikhs and other influential Mussulmans in India, and heard from them of the prosperity of the Mussulmans enjoyed under English rule. He therefore would be glad to receive and carry out any orders that might be sent him by the English Government, and do them very great service as no one would think of. And if he received encouragement from England he was not afraid of Persia or Turkey, for he had sufficient power. I said I would inform Her Majesty's Government of his good-will and intentions, which I was sure they would be glad to hear of. At present I was not aware of the exact nature of the reforms which it was desired should be carried out in the country, and that, therefore, I could give him no information on the subject, much less instructions; but I thought right to say that the Powers had no wish to overthrow or weaken the Turkish Government, but rather to strengthen and support it by bringing about such reforms as should give prosperity, security, and content to all nationalities. ${ }^{70}$

\footnotetext{
${ }^{67}$ Sheikh Ubeydullah's anxieties about an independent Armenia in the region can be found in FO 424/IO7, Captain Clayton to Major Trotter, Bashkala, July II, I880, reproduced in Turkey No. 5 (I88I), pp. 7-8. At various points, Khrimian directly challenged Sheikh Ubeydullah's efforts, see FO 424/Io6, Captain Clayton to Sir A.H. Layard, March 2, I880, perhaps more famously in FO 424/IO7, Letter from Monseigneur Krimian [sic], pp. 86-87, reproduced also in Turkey No. 5 (I88I), pp. 5-7; on Khrimian's ideology see Dzovinar Derderian, "Mapping the Fatherland: Artzvi Vaspurakan's Reports through the Memory of the Past," Houshamadyan (20I4); Sasuni I992, pp. I42-I6I. Incidentally while Mkrtich Khrimian initially fled from Van to avoid conscription, his great rival in Van, Archbishop Boghos Effendi, fought with Ottoman forces against Mehmet Ali's forces in the I830s. See FO 424/I62, "Career of Archbishop Boghos," Annex 3, in a dispatch from Vice-Consul Devel to Consul Chermside, Van, April I3, I889, p. 44. This tension between autonomy and conciliation with Ottoman power bears some resemblance to Ubeydullah's own rivalries with pro-Ottoman Sheikhs. One might draw a number of intriguing parallels between the lives and careers of Khrimian and Ubeydullah.

68 Ateş 20I4, pp. 786-789.

${ }^{69} \mathrm{FO}$ 424/I07, Captain Clayton to Major Trotter, Kochhanes, August 2, I880, p. I97.

70 Ibid.
} 
Emilius Clayton's cautious response to Ubeydullah's foregoing remarks made a great deal of sense given British policy, which was at this point mostly focused on 'containing' Russian expansion through supporting Ottoman centralization in the Eastern provinces and did not condone the creation of either an Armenian or Kurdish principality. ${ }^{71}$ According to Clayton, Sheikh Ubeydullah was "imbued with the idea that England desires to obtain territory here, and knowing her power, thinks it best to offer to throw in his lot with her, and by his hint meant he was prepared to hand over Kurdistan to her, in the hope of being rewarded by being himself a sort of Viceroy, or quasi-independent vassal, like some of the native Princes of India." 72

Significantly, Clayton proposed to "communicate to the Turkish authorities there the general conclusions I have arrived at with regard to the Sheikh's intentions and actions, as they are much deceived by their agents." ${ }^{\prime 3}$ Clayton was not alone in passing along confidential information to the Ottomans or others about the Sheikh's plan. Mar Shimun XVIII Rubil informed the Ottoman State of Sheikh Ubeydullah's plans and the American Urmia-based missionaries relayed Sheikh Ubeydullah's communications to the Qajar State. ${ }^{74}$

Throughout this period, the American missionaries frequently served as conduits of information between Sheikh Ubeydullah and the British Government. ${ }^{75}$ In late September and early October, Sheikh Ubeydullah sent two letters to Dr. Cochran, in both cases requesting that the letters be passed along to William G. Abbott, the British consul in Tabriz. ${ }^{76}$ In these letters Sheikh Ubeydullah wrote that as "neither the Ottoman nor the Persian Government have purity of intention" the time had come for action. ${ }^{77}$ The Kurdish nation, "a people apart," composed of 500,000 families with distinct religion, laws and customs, desired that "our affairs to be in our own hands." ${ }^{\prime 7}$ Soon after the letters reached the missionaries, at the beginning of October I880, Sheikh Ubeydullah and an army of between I0,000 and 30,000 soldiers seized the town of Savojbulagh (Mahabad) in Qajar territory. ${ }^{79}$ Sheikh Ubeydullah's rebellion had begun.

\section{Part II: Ubeydullah and the Missionaries in Urmia}

Sheikh Ubeydullah's rebellion was well documented by letters and diaries written by Urmia, Tabriz and Van-based missionaries. Over the course of the autumn of I880, Sheikh Ubeydullah tried his best to protect both the missionaries and the local Christian population from what

\footnotetext{
${ }^{71}$ Ateş 20I4, p. 748.

${ }^{72} \mathrm{FO} 424 /$ IO7, Captain Clayton to Major Trotter, Kochhanes, August 2, I880, p. I98.

73 Ibid, p. I99.

74 FO 424/IO6, Captain Clayton to Sir A.H. Layard, Van, February 2, I80, p. 247; [Mary Jewett] "Persia: Tabriz," Woman's Work for Woman: A Union Magazine, January I880, p. 303.

75 FO 424/I06, Rev. B. Labaree to Captain Clayton, Oormiah, January 30, I880, p. 273; FO 424/Io6, The Rev. J.H. Shedd to Captain Clayton, Oormiah, January 30, I880, p. 273; FO 424/IO7, An American Physician to Consul-General Abbott [Joseph Cochran], Orromiah, July 8, I880, pp. I28-I29, reproduced in Turkey No. 5 (I88I), pp. 9-IO; FO 424/I32, Dr. Cochran to Consul-General Abbott, Oroomiah [sic], September 6, I882.

${ }^{76}$ For an analysis of Sheikh Ubeydullah's letters analysis, see Soleimani 20I6, pp. I88-I98.

77 Turkey No. 5 (I88I), Sheikh Obeidullah to Dr. Cochran, September 25, I880, p. 47.

78 Turkey No. 5 (I88I), Sheikh Obeidullah to Dr. Cochran, October 5, I880, pp. 47-48.

79 Turkey No. 5 (I88I), Mr. Thomson to Earl Granville, Tehran, October 8, I880; more generally see Ateş 20I4, pp. 746-768.
} 
quickly descended into horrific sectarian violence, pitting Sunni against Shi'i populations on both sides of border. ${ }^{80}$ We might speculate that part of that might have been instrumental: Sheikh Ubeydullah knew the missionaries were protected by the British Government and were important conduits to public opinion in Great Britain and the United States. Sheikh Ubeydullah also seemed to believe that the missionaries were a benefit in themselves, being altruistically inclined and focused on projects of education and healthcare, in addition to evangelizing. Missionaries like Joseph Cochran and Henry Otis Dwight, who had spent most of their lives in the Qajar and Ottoman Empires, were also locals of sorts, and may have been valuable additions to a newly independent Kurdistan.

While the first generation of missionaries (arriving in Constantinople in I830 and Urmia in I834) were outsiders to the societies they evangelized, the children of the missionaries often grew up speaking the local languages without a trace of an accent and seeing the world through local lenses. This process of acculturation signals that the work of conversion was often a twoway street, and that the experience of living abroad for several generations profoundly shaped different communities of missionaries.

In the same way that Sheikh Ubeydullah exhibited radically different patterns of behavior from his father, Sheikh Taha, the 'second-generation' missionaries like Dwight and Cochran exhibited very different sensibilities than their 'first-generation' missionary parents.

In I830, around the time of Sheikh Ubeydullah's birth, Henry Otis Dwight's father, Harrison Gray Otis, had been charged by the ABCFM with exploring the eastern reaches of the Ottoman Empire. Most of those territories were still under the control of Kurdish emirates (miratî). Over the course of I8 months, Harrison Gray Otis and Eli Smith trekked some 2500 miles to explore what possibilities existed for the "revival and reformation of the Oriental churches in Armenia, Georgia, and Persia." "I It was partly due to these explorations in the early I830s that the Prudential Committee of the Boston-based ABCFM (at that time an umbrella organization of both Congregationalists and Presbyterians) established a mission in Urmia in I835.

The spread of the ABCFM coincided with the Ottoman State's conquest of the Kurdish emirates during the $I^{\text {th }}$ century and the rise of the Naqshbandi Sheikhs. The ABCFM were accorded protection both by the Ottoman State and by the British Foreign Ministry. The ABCFM were, at least at first, ardent proponents of Istanbul-based centralization, seeing the "line of civilization" in the line of garrisons that extended further into the mountains. Until the reign of Abdülhamid II (r. I876-I909), the Ottoman State protected the American Board missionaries from attacks from their rivals, often connected to the Armenian and Assyrian churches. ${ }^{82}$

The British, concomitantly, relied heavily on the ABCFM-information network. ${ }^{83}$ The ABCFM missionaries and their Ottoman Protestant community collected large amounts of

\footnotetext{
80 Ateş 20I4, p. 752.

${ }^{81}$ Eli Smith and Harrison Gray Otis Dwight, Missionary Researches in Armenia: Including a Journey Through Asia Minor, and into Georgia and Persia with a Visit to the Nestorian and Chaldean Churches of Oormiah and Salmas (London: George Wightman, Paternoster Row, I834), p. ix.

${ }^{82}$ For a brilliant discussion of the breakdown of these relations, see Hans-Lukas Kieser, The Nearest East: American Millenialism and Mission to the Middle East (Temple University Press, 20IO), p. 56.

83 Bryce I896, p. 467.
} 
information - everything from maps and population estimates to the personalities of various governors. In exchange for all of this information, the British Government acted as the protectors of the ABCFM missionaries and the Ottoman Protestant community.

In both the Ottoman and Qajar Empires, the ABCFM/Presbyterians increasingly shifted their focus from spreading the Word to spreading institutions like schools (for boys and girls), orphanages, hospitals and colleges. The 'second-generation' missionaries were far more connected to local communities, and often reflected local points of view. As the second-generation missionary Frederick Greene put it, whereas he had once been a missionary to Armenia, he was now a missionary from Armenia. ${ }^{84}$ Frederick Greene, frustrated with the censorship of the Missionary Board in the wake of the Hamidian massacres against the Armenians, became a journalist for the Manchester Guardian. ${ }^{85}$

In the age of the telegraph, the line between missionary and journalist was often a very thin one, if it existed at all. From the beginning of the ABCFM endeavors in the Ottoman and Qajar Empires in the I830s, missionaries had written dispatches designed to be pared down and published in the missionary press. By the end of the I9th century the missionary press was integrated into the mainstream press. The result was a dramatic expansion of the narratives disseminated by the ABCFM missionaries. Some missionary children, like Henry Otis Dwight, became practicing journalists. Others, like Benjamin Labaree, Jr. made sure their letters appeared in the press. ${ }^{86}$

It was through these widely-published letters that many in Great Britain and the United States learned of Sheikh Ubeydullah and his rebellion. In the press, while the armies he led were criticized harshly, Ubeydullah was spoken in glowing terms. According to the missionaries, during the violence Ubeydullah himself ordered that the missionaries and the Christians of the Urmia plains were to be treated as if they part of "his own family." 87 During the violence, Sheikh Ubeydullah posted guards around the missionary compound in Mount Seir, near Urmia, to protect the missionaries, and the several hundred Muslims, Shi'i and Sunni who sought refuge with them. ${ }^{88}$ During the siege of Urmia the missionaries felt they were caught "between two powers, trying to avoid bloodshed." ${ }^{89}$ Nevertheless, they were convinced that "the Sheikh is our firm

\footnotetext{
84 B.O. Flower, The Arena, vol. I3, page xi.

85 See, Frederick Davis Greene, "The Armenian Massacres," (May I, I895); idem, "An Armenian Revolution," (May II, I895); and idem, "The Sasun Community," Manchester Guardian.

${ }^{86}$ It is interesting to note that Benjamin Labaree Sr. Wrote frequently in the missionary press while his son wrote directly to the mainstream press. See Benjamin Labaree, Sr., "The Recent Revival in Oroomiah," The Foreign Missionary, Vol. 45, vol. 5 (October I886), p. I99; idem, "A Nestorian Evangelist," The Church at Home and Abroad, Vol. I (I887), pp. 565-566; Benjamin Labaree, Jr., "Reports directly from Benjamin Labaree of Seir," Plymouth Restitution (Indiana), January I2, I88I.

87 Katherine Hale Cochran, October I8, I880, quoted in Speer I9II, p. 84; Benjamin Labaree, Sr., November 4 , I880, in Speer I9I I, p. 93.

88 [Sarah Shedd], "Oroomiah College, Persia," in A History of the Establishment of Diplomatic Relations with Persia (Marietta, Ohio, I887), p. I6; Katherine Hale Cochran, October 2I, I880, in Speer I9II, p. 85.

${ }^{89}$ Katherine Hale Cochran, October 2I, I880 in Speer I9I I, p. 86.
} 
friend, and will not see us harmed" and that Sheikh Ubeydullah went through great lengths to prove this. ${ }^{90}$

By the beginning of November, the missionaries reported that the Kurdish army began to dissipate in the face of large Qajar forces..$^{9 \mathrm{I}}$ According to the missionaries, the arrival of the Qajar army under the command of Taimur Paşa was for many of the inhabitants of the Urmia plain "worse than the Kurds" as they continued to plunder villages and did "dreadful things." 2 The violence between the Shi'i and Sunni communities continued to spiral out of control. According to Dr. Shedd, by December I880, "Shias were killing Sunnees, and Sunnees, Shiah, as if either party were wild beasts. The Sunnes were all driven out of the country or killed, except a few who changed their form of faith." 93 Tens of thousands of Sunni refugees fled from the plains of Urmia into Ottoman territory, and "those who remained and were discovered were killed, and their villages plundered." 94 According to Captain Clayton, this violence continued into the next summer as the Qajar army continued to commit "great barbarities, burning villages and putting women and children to the sword." 95 As Sabri Ateş has perceptively pointed out, the Qajar campaign was not just a campaign of vengeance but also "an attempt to extend the authority of Tehran into the borderlands." 96 As was true at the edges of Ottoman control, the efforts to centralize authority in the Qajar Empire often looked like conquest.

By January I88I, Sheikh Ubeydullah's movement had entirely collapsed, and many of his supporters, along with numerous refugees, had returned to Ottoman territory. ${ }^{97}$ The response of the Ottoman State was curious. In response to Qajar demands, in the summer of I88I, the Ottoman State exiled Sheikh Ubeydullah to Istanbul. While Sheikh Ubeydullah's territories in Shemdinan went unmolested, four Ottoman battalions systematically plundered and destroyed the villages of his close allies. ${ }^{98}$

\footnotetext{
${ }^{90}$ Katherine Hale Cochran, October 2I, I880 Speer I9II, p. 86 and undated letter from one of Joseph Cochrans's sisters p. 96; [Sarah Shedd], "Oroomiah College, Persia," in A History of the Establishment of Diplomatic Relations with Persia (Marietta, Ohio, I887), p. I6.

${ }^{91}$ Katherine Hale Cochran, November I, I880, in Speer I9II, p. 90, for analysis of why the Sheikh withdrew, see Ateş 20I4, pp. 753-755.

${ }^{2}$ Katherine Hale Cochran, November 5, I880, in Speer I9II, p. 9I; see also Dr. Joseph Cochran, November 8 , I880, in Speer I9II, p. 92; Wilson I895, p. II5.

${ }^{3}$ Dr. Shedd, January 3, I88I, in Speer, I9I I; see also FO 424/I22, Captain Clayton to Major Van, November 27, I880, p. I0; FO 424/I22, Captain Clayton to Major Trotter, Van, November 23, I88o, p. 8 and Captain Clayton to Major Trotter, Van, December 29, I880, p. 60.

94 Wilson I895, p. II5. Ateş (20I4) estimates that between I5,O0O and IOO,OOO families of refugees crossed into Ottoman territories, see p. 763 and fn. I53, p. 770. According to Clayton, the numbers to Hakkâri were much smaller, see FO 424/I23, Captain Clayton to Major Trotter, Van, May 24, I88I; the Ottoman government noted that about "60,000 to 70,000 persons" fled Qajar territories, Turkey No. 5 (I88I), Note from the Sublime Porte, November 29, I880, p. 65.

95 FO 424/I23, Captain Clayton to Major Trotter, Van, August 23, I88I, p. I59. See also, Turkey No. 5 (I88I), Consul-General Abbott to Mr. Thomson, Tabreez, November I9, I880, p. 52.

${ }^{6}$ Ateş 20I4, p. 74I, see also, p. 767.

97 Turkey No. 5 (I88I), Earl Granville to Mr. St. John, January 7, I88I, p. 73; FO 424/I32 Herbert Chermside, "Notes on the Kurdish Movement," p. I59.

${ }^{98}$ Chermside, "Notes," op. cit, p. I60.
} 
This differential treatment may be partly explained by the reception that Sheikh Ubeydullah was given as he was escorted to Istanbul. In Van, "the whole Moslem population went out to meet the Sheikh, to kiss his hand, and implore his blessing" and "there is no doubt that the sympathies of the Moslems are with the Sheikh rather than with the [Ottoman] Government."'99 Upon his arrival in Istanbul, Sultan Abdülhamid II apparently "kissed his hand and had a long talk with him on the state of the country and the best means of extricating the Empire from its difficult position."IO0 According to Dwight, writing in the New York Tribune, such was the regard held for Sheikh Ubeydullah that "it has even rumored that his Kourdish chieftain [sic] might soon become Grand Vizier."'Ior

In a series of confidential reports to the missionary board in Boston, Dwight noted that Sheikh Ubeydullah upon arriving in the city, had immediately reached out to the missionaries. According to Dwight, Ubeydullah was "intensely interested to know why foreigners love the Armenian so much and do not love the Kourds; why Christians abroad take an interest of the people of this country at all; and Christian lands like England and America are rich and rise, and noble while Moslem lands are poor and feeble" (emphasis added). ${ }^{\mathrm{I0}}$

It is likely that Dwight was cognizant of Sheikh Ubeydullah long before he arrived. An avid reader of the Ottoman-language press, Dwight was also well connected to missionaries in both the Ottoman and Qajar Empires.

However, there was a closer relation. One of Sheikh Ubeydullah's relatives had converted to Christianity and joined the American Board missionaries in Istanbul. This hitherto unreported follower of Ubeydullah was at the center of the conversation between Ubeydullah and Dwight.

\section{Part III: Ubeydullah and Dwight in Istanbul}

The ABCFM and the Naqshbandi Sheikhs had both spread in the mountainous east in the wake of the Ottoman conquest of the mountains. [Fathers of Ubeydullah and Henry Dwight] Seyyid Taha and Harison Gray Otis Dwight had each spent their careers on revivalist projects, stressing clear-cut distinctions between Islam and Christianity. However, the careers of their sons, who bore many commonalities in temperament and upbringing with each other, took different paths. In the fall of I88I, Ubeydullah and Henry Dwight found that their conversation was free and uninhibited. Seeking a middle ground was perhaps key because of their central experiences with wars.

In the case of Sheikh Ubeydullah, the Russian-Ottoman War of I877-I878 was central to his decision to create an independent polity. For Dwight it was the US Civil War, whose outbreak had cut short his education at Wesleyan University in Ohio. Dwight came from a family that maintained strong radical abolitionist views. This is not in itself surprising. The history of abolition in the United States was interwoven with the same communities that sent missionaries

\footnotetext{
${ }_{99} \mathrm{FO}$ 424/I23 Captain Clayton to Major Trotter, June 2I, I88I, p. 22; Sheikh Ubeydullah received a similar treatment in Erzurum, FO 424/I32 Major Everett to Major Trotter, Erzeroum, September I882, p. I89.

${ }^{100}$ [Henry O. Dwight], New York Tribune, September IO, I880, see Ateş 20I4, pp.775-776.

IOI Ibid.

${ }^{102}$ ABCFM 600/327, Dwight to Rev. Clark. August I6, I88I.
} 
to far-flung areas in Hawai'i, the Ottoman Empire and China. One of the largest efforts to establish colleges for African-Americans during the post-war Reconstruction was carried out by the American Missionary Association (AMA), a splinter group of the ABCFM. The ways in which this abolitionist sentiment played out around the world have seldom been studied, but it shaped for many their approach to local conditions.

For instance, Justin Perkins, who served as a missionary for many years in Hakkâri, expressed these sentiments clearly in a letter to the abolitionist Lewis Tappan in I84I,

The condition of the Nestorian Christians, too, for whose salvation we are more particularly laboring, is such as often to remind us of the slaves in America. They are trodden down to the dust by their Mohammedan masters, not for difference of color, but for bearing the name of Christ. It is truly affecting to witness their degradation, and, often, their sufferings. There is, however, but a small comparison between the rigors and the horrors of their condition, and that of the southern slave... Yes, though I blush, and my heart sinks within me at the acknowledgment, yet truth and candor compel me to say, that in all my travels and residence, in these dark realms of MOHAMMEDAN DESPOTISM, I have seen nothing in the shape of oppression to equal, and scarcely to bear a comparison with the rigors and abomination of that under which millions of immortal beings are at this moment groaning, in our own CHRISTIAN, PROTESTANT, REPUBLICAN, AMERICA. ${ }^{103}$

Such was the enthusiasm of many New England Congregationalists for the anti-slavery movement that many of the children born abroad were quick to volunteer in the fight against slavery. Dwight was one of these, an early volunteer for the Union army.

Dwight served in the $20^{\text {th }}$ Ohio regiment, surviving the long year war to return 'home' to Istanbul. After the war, Dwight served first as the business agent for the American mission and then for the publication department. Over the course of the next three decades, Dwight edited Armenian and Ottoman-Turkish language newspapers, worked on a translation of the Bible into Ottoman Turkish and edited and led the editing team that produced the massive Redhouse TurkishEnglish dictionary of $\mathrm{I} 890 .{ }^{\mathrm{I} 04}$ It was during these years of labor at the Bible House in Istanbul that Dwight first met Keffee Effendi, a central figure in the conversation with Ubeydullah.

Keffee Efendi - quite possibly a pseudonym - is a thoroughly fascinating and elusive person, whose presence can only be faintly documented in missionary publications. ${ }^{\mathrm{IO}} \mathrm{He}$ is also central to the conversation between Dwight and Ubeydullah. According to Rev. Edwin M. Bliss, Keffee

${ }^{103}$ Justin Perkins, Letter from an American Missionary in Persia (22 Jan. I84I), Emancipator 6 (24 June I84I), p. 29, quoted in Charles A. Maxfield, “The 'Reflex Influence' of Missions: the Domestic Operations of the American Board of Commissioners for Foreign Missions, I8IO-I850," PhD dissertation, Union Presbyterian Seminary, I995.

${ }^{104}$ The National Cyclopædia of American Biography, vol. X (New York, James T. White \& Company, 1990), p. 490, see also Amerikan Bord Heyeti (American Board), Istanbul, "Memorial records for Henry O. Dwight," American Research Institute in Turkey, Istanbul Center Library, online in Digital Library for International Research Archive, Item \#I6852, http://www.dlir.org/archive/items/show/I6852 (accessed January 23, 20I9). ${ }^{105}$ Henry Otis Dwight's I9I3 novella A Muslim Sir Galahad is almost certainly based on the life of Keffee. 
Efendi was, "a Kurd of the Jaff tribe near Suleimanieh." Years later, in an article in the Andover Review, Bliss recollected that,

\begin{abstract}
"He was one of the most remarkable men it was ever my privilege to meet. A thorough scholar in Turkish, Arabic, and Persian, as well as his own Kurdish, he had also a very wide knowledge - though he knew no European languages - of other countries, their history, geography, and general characteristics. With a capacity for patient research he combined a quick perception, evenly balanced judgement, and conscientious faithfulness, very unusual in an Oriental. As a young man he was employed by the famous Sheikh Obeidullah to travel through Central Kurdistan and gather facts about the different tribes. Subsequently, in Mosul he became interested in Christianity, and came on to Constantinople, where was employed as a scribe on the Committee for the Revision of the Turkish Scriptures. He became, as we believe, a true Christian, and was eagerly planning for the translation of the Bible into his own language when he was struck down by typhoid fever, in the spring of I883, a great loss to his associates and especially to his people."
\end{abstract}

It was almost certainly Keffee Efendi who introduced Dwight to Sheikh Ubeydullah in October of I88I.

Dwight's confidential report of the conversation reveals Ubeydullah's nonconformist religiosity. According to Dwight, Sheikh Ubeydullah spoke very favorably of ABCFM missionary work and that "it was good and only good." as pure as an ideal Muslim and were truly servants of God although they had not the Moslem name." ${ }^{108}$ At the same time, in his own writing Sheikh Ubeydullah questioned the religious sincerity of many of his co-religionists in the Ottoman and Qajar Empires.

Rather than religious formalism and consequential theological differences the sheikh emphasizes the practical outcome of a religious agent's devotion (of either faith) and the ways in which heartfelt beliefs are reflected in one's action. Sheikh Ubeydullah appears to have perceived religions merely as different expressions of a singular fundamental "truth." And yet too often their followers fail to see this underlying unity. To underscore this point, in the midst of the conversation, Sheikh Ubeydullah drew from the work of the I3th century Sufi poet, Jalāl al-Dīn Rūmī. ${ }^{109}$

Ubeydullah said, "We seek what you seek." The Sheikh continued,

"In the great religious poem of the [Rumi's] Mesnevi is the story of four men who found
some money in the road, one was a Persian, one a Turk, one a Kourd and one an Arab.
Each one said in his own language 'Let's buy grapes with it and eat them together.' But
neither could understand the other and so they fell to fighting... thus they were nearly
killed [when] a fifth man came along and asked what was the matter. 'Why he exclaimed

${ }^{106}$ Edwin M. Bliss, Andover Review, vol. 4, July-December I885, p. 22.

${ }^{107}$ ABCFM 600/328, Dwight to Rev. Clark, October I2, I88I, p. 2.

${ }^{108}$ Ibid. Dwight noted this with an exclamation point.

${ }^{109}$ In his poetic oeuvre, Sheikh Ubeydullah goes so far as to claim that his entire project involved in reviving Rumi's Masnavi. 
you all want the same thing only you don't know it! This is the way with many of our differences on religious questions."”по

Ubeydullah's reference to Rūmī was key. Rūmī contended that, the "main purpose of prophets and religions is to cultivate people's spirits and heal their soul, not to fill their minds with learning, but to fill their hearts with the love of God and love for one another and to cleanse them of sickness and hatred."III In his poetic story of Moses and the Shepherd-where God criticizes Moses for the latter's rigid religious formalism— Rūmī, himself, sums up his idea of the unity of religions

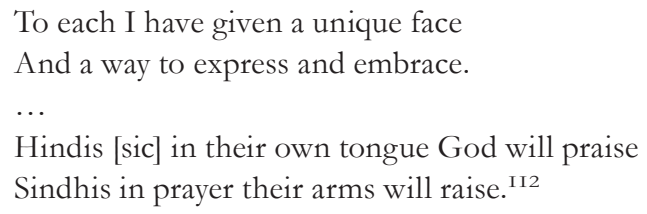

It is not clear how freely Sheikh Ubeydullah shared these views with his followers and the people around him. And while it should be noted that previous masters of the Naqshbandi Order, such as Mawlana Khālid and Ahmad al- Sirhindī had also emphasized the "inner aspect" of the shari'a, Sheikh Ubeydullah was going much further down a road of respect for religious Others.

At some point in the conversation, the subject turned directly to Kaffee Effendi. Dwight notes in his confidential report that Keffee Effendi was "a relative of Sheikh Obeidullah and I believe a thoroughly good Christian man." Sheikh Ubeydullah had apparently been warned by the Ottoman government to have nothing to do with this scribe and that he was an 'infidel.' Sheikh Ubeydullah replied that "If this scribe is an infidel he wishes his whole nation was composed of infidels." "II3

Sheikh Ubeydullah's approach to Keffee Efendi's conversion to Christianity certainly put him at odds with mainstream Sunni and Shici Muslims of his era. Historically, since the introduction of the institution of Caliphate in Islam (632 CE) Muslims have legislated death for apostasy. All schools of Islamic law (shari'a) view conversion as a capital offense and punishable by death. Even modern Muslim reformists have defended such a penalty for leaving the fold of Islam. Reformists such as the Egyptian Muhammad 'Abdu, locate apostasy outside of individual human rights by regarding it as danger to the social order. Traditionalist figures such as Pakistani Abu al-'Ala Maududi and Egyptian Mohammad al-Ghazli have called apostasy an act of rebellion

\footnotetext{
II0 ABCFM 600/328, Dwight to Rev. Clark, October I2, I88I, pp. 4-5.

II I Abdolkarim Soroush, "An Islamic Treatise on Tolerance," in Kelly James Clark (ed), Abraham's Children: Liberty and Tolerance in an Age of Religious Conflict (Yale University Press, 2OI2), p. 282.

${ }^{112}$ Translated from Farsi to English by Shahriar Shahriari. http://www.iranchamber.com/literature/jrumi/ masnavi/moses_shepherd.php (accessed January 23, 20I9). See also, Jalāl al-Dīn Rūmī, Masnavi, Book 2, translated by Javad Mojaddedi (Oxford University Press, 2007), p. IOI.

II3 ABCFM 600/328, Dwight to Rev. Clark, October I2, I88I, p. 8.
} 
against the socio-political order rather than a mere change of religious beliefs. ${ }^{\text {II4 }}$ Sheikh Ubeydullah's unconventional approach to religious conversion could help explain the sheikh's relations with his Christian neighbors. As a Sunni, Sheikh Ubeydullah was expected to advocate Keffee Efendi's death. Nevertheless, he regarded Keffee Efendi as a paragon of piety and a role model for his Kurdish countrymen to emulate.

Dwight seemed to share Ubeydullah's respect for the religion of the Other. In I887, Dwight penned a detailed religious and historical analysis of the Naqshbandi order. Here Dwight stressed that the Qur'an was "a book which contains some of the truths of God" and that in order to convert Muslims to Christianity, "time is well spent which is given to the study of the inner facts of Islamism."II5 Dwight also recalled, again, his conversation with Sheikh Ubeydulah, especially on the subject of the "change of heart which God's spirit can effect."

He was fully as much astonished to learn that there are Christians who believe in the necessity of regeneration as I was to hear him say he had seen repeated instances of it through the spirit of God working in the hearts of his own followers, the men having been turned from vice to purity and piety. Afterwards he remarked to one of his Moslem friends, referring to this talk, and to his acquaintances with American missionaries in Persia, "To say that these Americans are not the people of God's guidance is to confess one's self a fool. Yet if we believe the Koran, we must say that these people are unbelievers, or be unbelievers ourselves. For my part, I hold that in the sight of God an unbeliever of this sort and a Moslem are both one."

\section{Conclusion}

Henry Otis Dwight and Sheikh Ubeydullah each evinced in the conversation a very clear idea of what was 'right' but at the same time a sympathy for those who believed differently. Sheikh Ubeydullah's father, Seyyid Taha, reportedly ordered that a woman who had left the fold of Islam be stoned for apostasy. ${ }^{117}$ Sheikh Ubeydullah continually advocated for the protection of the Christian population, commended the American missionaries for their nearness to Godly action, and praised the actions and beliefs of an apostate. While it is easy to assume that these actions were instrumental, it appears just as likely that they showed a genuine respect for the religious Other, based at least in part in getting to know them as individuals. Likewise, while Dwight had grown up in a household of missionaries, bent of 'saving' the 'Mohammedan' Other and the 'nominal' Christian, he often wrote vividly about the beauty of Islam and its expressions, such as the Muslim call to prayer, "the beautiful words ringing out upon the

\footnotetext{
${ }^{114}$ For an excellent discussion of apostasy in the Ottoman Empire, see Selim Deringil, Conversion and Apostasy in the Ottoman Empire (Cambridge University Press, 20I2)

${ }^{115}$ Henry Otis Dwight, “Theological and Religious Intelligence: Notes on the Nakshibendi Dervishes," The Andover Review, Vol. 8 (August I887), p. I86.

${ }^{116}$ Ibid, p. 201.

${ }^{117}$ The Missionary Herald, vol. 44 (I849), p. 56
} 
stillness and darkness of the night from the lips of the worshipper upon the slender tower above the mosque."

This same process can be seen in this journal, The Muslim World. In the first issue of The Moslem World, published in I9I I, the Rev. Samuel Marinus Zwemer asked for "the cordial cooperation of all those who have made special study of any phase of Islam, and who can from their experience show others how to win Moslems to Christ." "I9 It is now dedicated not to evangelizing but to the "promotion and dissemination of scholarly research on Islam and Muslim societies and on historical and current aspects of Muslim-Christian relations." 20 This is not a

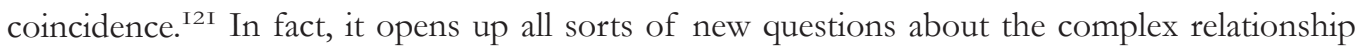
between conversion, education and the ability of convinced believers to respect religious Others.

\section{Acknowledgements}

We would like to thank Metin Atmaca, Eliza Gheorghe, Matthew Ghazarian, Onur İşçi, Dwight Miller, Anthony K. Shin, and Metin Yüksel for reading and commenting on our paper.

\footnotetext{
${ }^{118}$ Henry Otis Dwight, Constantinople and Its Problems: Its Peoples, Customs, Religions and Progress (New York, I9OI), p. 52.

119 The Moslem World, vol. I (I9II), p. 3.

${ }^{120}$ This same pattern can be seen with Union Theological Seminary, another central I9th institution in the ABCFM's attempt to convert the world.

${ }^{121}$ See David A. Hollinger, Protestants Abroad: How Missionaries Tried to Change the World but Changed America (Princeton University Press, 2017).
} 